\title{
INTERROGATING THE ROLE OF DEMOCRACY IN PROVIDING SOCIAL POLICIES FOR PEOPLE WITH DISABILITIES: INSIGHTS FROM SOUTHEAST ASIA
}

\author{
Fadillah Putra \\ Public Administration Department Faculty of Administrative ScienceUniversitas Brawijaya
}

\begin{abstract}
In developing countries the quality of life of their citizens is far from democratic principles. Many are found in public spaces that not support the existence of accessible services for persons with disabilities. Among many exclusion issues, this essay wants to focus on disability, which is related to the low attention of the government to people with disabilities' accessibility and representation. Social exclusion especially to people with disabilities strongly related to the concept of power relation. This implies that the social transformation (democratisation) will occur when the political system guarantees the power and power relations to be recognised by each individual in the society. Using "power relation" concept in Foucauldian perspective in analyzing social policy of four South East Asian governments, namely Indonesia, Malaysia, Thailand, and Philippine, this shows that there is a need for a review of the democratization process.
\end{abstract}

Keywords: Disability, Social Policy, South East Asia, Democracy

\section{Introduction}

The improvement of the citizen's quality of life, especially the minority ones has been far from the impact of democratisation in developing countries, though it has been conducting for more than a decade. People with disabilities, for instance, remain excluded from the public sphere even in democratised developing countries. This is the point where the trajectory of democratisation needs to be questioned and re-analysed. It is a debatable point whether democracy successfully transforms the society to be more equal and less violence in any forms. To this extent, one of the major problems that remain

* Corresponding author: Fadillah Putra

fadil putra@yahoo.com

Published online at http://IJDS.ub.ac.id/

Copyright @ 2018 PSLD UB Publishing. All Rights Reserved unsolved is the problem of exclusion, which simply means marginalisation of certain communities by the system (Levitas 1996). Among many exclusion issues, this essay wants to focus on disability, which is related to the low attention of the government to people with disabilities' accessibility and representation.

The concepts of power relation and electoral incentives will be applied in order to unravel the problem of democratisation and social exclusion. This perspective argues that democracy is not a matter of consensus or peaceful agreement among people; rather it is a continuing process of power struggles and conflicts. In his idea of "care of the self", Foucault insists that due to the fact that identities and differences within society are inevitable facts, therefore; conflicts become unavoidable as well. Once

Received, October $9^{\text {th }}, 2018$ 
conflict takes place, 'power' will be the main ingredient of every social interaction. Therefore, in Foucauldian perspective 'power relation' becomes the basis in analysing every social phenomenon, including democracy.

\section{Democracy and State Responsiveness}

There are two ways in which democracy can be categorised. The first way is based on how democracy facilitates the aggregation of political interests. There are two types of democracy in this regard: majoritarian democracy (the power of majority) and consensus or deliberative democracy (the power of agreement). The second categorisation is based on the value in it, which commonly known as liberal democracy (value freedom) and social democracy (value equality) (Ido 2012). Above all, Peter Schumpeter (in Ido 2012) argued that as long as there is regular election, free political competition and absence of repressive power to control over the everyday politics, the political system can be classified as democracy.

One reason why democracy is necessary, because it guarantees equal respect to the citizen's basic rights compared to authoritarian system. However, in the reality of democratic countries, certain communities remain excluded from economic and social circuits. This is a new challenge; democracy has to face, especially in developing countries. There are two versions of exclusion: first is weak version when a person excluded because his willingness to include is low; and the second is strong version when the social and economic institutions make him excluded (Sen 2000 and Martin 2004). People with disabilities have been excluded in the strong version, especially in developing countries, as the education system, job market regulation, infrastructure and public services in general are not designed in a way in which people with disabilities easy to access. If this problem remains unsolved, democracy will violate its own goal to protect the citizen's rights.
The mechanism in which democratic states can be more responsive to the needs of people with disabilities is through social policy. The impact of democracy on social policy may also be found in Christopher Hewitt's "simple democratic hypothesis" (in Roberts, 2005). His hypothesis argues that democracy enables a mechanism in which the demand of the poor and other marginalised groups (including persons with disabilities) are possible to enter policy development agenda. A pro-poor policy takes place as the result of electoral incentives from a free and fair election. Such mechanism occurs particularly in a country which use a plurality election system and wherein majority of the voters are poor. As Haggard and Kaufman (2008) emphasised such question by stating that among any other variables, democratic political institutions hence become a distinguished variable affecting the direction of social policy. Although the impact of democracy to social commitment cannot simply be generalised across developing countries but it is hard to say that there is no connection between democracy and social policy.

In fact, there are a couple of empirical evidences which support those arguments. A study conducted by Nelson (2007) discovers that by measuring government spending on social welfare programs, a competitive election significantly affects social policies. The research conducts an analysis on a series of data since the late 1990s to 2006. More than 20 cross-national quantitative studies have since tested the hypothesis. According to the study, there are several arguments which may explain why democracy endorses greater welfare programs. First, politicians claim credits and benefits from an expanded patronage opportunity. There are infinite instances in which candidates seek support by offering an increased spending on social services. Moreover, the second one is related to the vested interest theory which argues that democratisation is likely to enhance the relative power of unions (network). Competitive elections may urge political parties to establish an alliance with either teachers' or health workers' unions to gain 
their political supports. Then, electoral democracy increases the representation of left-leaning parties in public policy development which then endorses social policy (Nelson, 2007). Data in Figure 2 indicates that there is a potential relationship between democracy and social policy especially in term of health spending.

Social policy produced by democratic system eventually will enhance well-being of the citizen. The term well-being, quality of life, and welfare are used interchangeably. The meaning simply refers to the resources that a person is able to command and his ability to achieve his goals due to those resources he has (McGregor 2007). This sort of concept has deeper understanding in measuring 'welfare' compared to macro economic concepts, such as GDP, economic growth, or income per capita. One of the most important aspects of well-being is "social well-being". Corey Lee Keyes (1998) defined social well-being as the appraisal of one's circumstance and functioning in society which can be seen from her acceptance, integration and contribution into the society. The United States Institute of Peace (USIP) defines social well-being more comprehensively as "an end state in which basic human needs are met and people are able to coexist peacefully in communities with opportunities for advancement". This end state is characterized by equal access to basic needs services which includes: water, food, shelter, and health services (USIP 2012). Here, democracy has to prove its capability in improving the citizen's social well-being as the "welfare reward" of practicing democratic principles.

Jutta Heckhausen (1999) stated that psychological modes of regulation of the life course have been more important than political or institutional constraints in determining individual's well-being. On the other hand, Mayer (2009) argued that social and cultural constructions are significant in shaping the well-being of both individual as well as society. Mayer's stand point was echoed by Thomas A. DiPrete (2002) which explicitly stated that state's ideology is matter in shaping well-being of the citizen.
The liberal and social-democratic regimes will produce the different kinds of wage and employment policies which will push the well-being trajectories toward the different directions.

\section{Inclusive Social Policy}

Social exclusion can be defined in two versions. First is "weak" definition of social exclusion which believes that an individual being excluded is because of his lack of capability or willingness to include in the system. The second is "strong" definition which argues that a person become excluded because of there is a mechanism of the system through which making him excluded. Social exclusion quantitatively can be measured by the number of participation (especially for excluded communities) in political and policy events, access to services, participation in permanent job especially of the most vulnerable socially excluded people, such as people with disability, women, and minority (Levitas, 1996). Both inequality and social exclusion are the basic problems of contemporary industrialised society that government - through social policies - have to solve.

Social exclusion especially to people with disabilities stringly related to the concept of power relation. Power relations in democratic society can be identified by the concept of identity in which individual perceives and posit himself toward others (Rainbow 1997). The way in which identity formulated is relative to which type of power the person relates to in certain social interaction. For instance, the society where physical disability is perceived as a disease and 'non normal' will put person with disability as a burden to others. The 'normal' people will identify themselves at the higher position relatively to people with disabilities; therefore 'normal' people would play sovereign or pastoral power to control people with disability to act in accordance to 'normal' standard. People with disabilities will be excluded from the 'normal' world, as they cannot meet the standard of normality in the society. Deaf and mute people cannot reach certain level 
of education as the school does not accessible to them, is one example.

The exclusion can be exercised by, for instance, put the people with disabilities in special schools, hospital or special settlements, which are separate from the 'normal world'. Sovereign power would take place when 'normal' system forcing the process of exclusion through its legal authority (strong version) while pastoral power conducting it by persuasion. In this situation, at the same time, people with disabilities also identified themselves detach from the 'normal' world which will determines the power relations between them with their others (the 'normal' people). The similar mechanism also applies to other forms of differentiation, such as economic status, ideology, religion, sex orientation, capital ownership, or centreperiphery. This is the mechanism of how identity determines the power relations between individuals, communities, individual toward community, or community toward.

Further, identity and power relation mechanism makes the concept of representation and conflict become natural in every human interaction (Fendler 2010). Back to the example of disability issue, once a person with disability are excluded from the 'normal' world and certain power relations takes place in that exclusion process, the tension between two different identities (normal and non-normal) will occur. The tension is the consequence once identity and power relations are recognised especially by excluded people, which eventually leads them to find the form of their representation within their community as well as to other. Therefore, Foucault concluded that identity, power relation and conflict altogether are the main ingredients of the society and its dynamics.

This implies that the social transformation (democratisation) will occur when the political system guarantees the power and power relations to be recognised by each individual in the society. However, this system does not come with recognition of representation. The marginalised communities must struggle against the dominant power in order to make their representation be recognised. For people with disabilities, who have been placed them in the "special" spaces and hide from the public spheres, there are at least two barriers they have to deal with. First, it is harder for them to access the infrastructures and communication instruments as the media to represent themselves in the public spheres. The second barrier is once they succeed to express their idea in public; it does not mean the public will automatically recognise the representation people with disabilities especially in political realm. It leads to the next question, how Foucauldian perspective explains the process of struggle against domination as a fuel of social movement, especially for people with disabilities.

With the problem of exclusion of people with disabilities, it is almost impossible to expect 'normal' people to provide solution for disable people's risks, because they are the creator of the risk. By 'creator of the risk' does not imply that 'normal' people are bad people, they just cannot represent people with disabilities. Take an example of the most common risks that is the risk of unemployment. The normal people have set up a certain qualification for people who wish to enter the job market. Education system and work infrastructures have also been set up in order to provide human resources who meet that qualification standard. These aspects eventually make people with disabilities become unemployed, as they cannot access education and infrastructures, therefore they cannot reach the qualification standard of job market.

Social policy is defined as the policy that directly provides more benefits for the poor, working class, seniors, marginalized women, people with disability, and any other socially excluded group of people (social well-being). Therefore, social policy often related to activities of governments in providing budget, setting regulation and forming institution in the areas of social security, healthcare, education, personal social services, housing provision and subsidies (Glennerster, 2009; Baldock 2012). Therefore, social policy is the main 
instrument in solving the problem of social exclusion.

\section{Southeast Experiences}

\section{Policies for People with Disabilities under Undemocratic Regimes}

Indonesia experienced undemocratic regime under Suharto era which pursued a rapid economic growth have then generated a fundamental weakness of social policy, a deteriorated democratic system, and a restricted enforcement of human rights (BTI, 2012). Looking at some examples, his very strict controls were imposed over unions, mass media and political parties (NDI, 1997) and most of it, over labour union. The New Order regime forbade labours to set up any new union and then forced them to join government-formed ones (USAID, 2008). The urgent demand for social policies among non-workers was also weak because civil society organisations were systematically undermined by the regime. This is the evidence of how the autocratic political institutions give direct negative effect to the development of social policy institutions. Historically, social welfare services emerged after the first two decades of the New Order regime. In 1983, the government issued Presidential Decision No. 39/1983 on welfare for disabled people. And in 1992, the government developed a program of social policy in the health sector through the Health Law No. 23/1992 (WHO, 2006). These facts hence indicate a slow development of social policy in this era.

Different to Indonesia, the low commitment of Malaysian government to democracy did not make its social policy to be significant. In 1988, they issued the policy of $1 \%$ job opportunities for persons with disabilities in the public sectors. It aimed to facilitate those disable persons qualified to get a decent position and salary in any public sector (MoW 2013). Social policies in Malaysia also covered more grounds, including the 1999 National Welfare Policy which provided a greater allocation of funds and a wider scope on social policy in Malaysia (DWS 2008).

Despite the low commitment to democracy, the Malaysian government manages to be proactive in developing social policies. In 2006, the Ministry of Women, Family and Community Development launched a grant of up to a maximum of USD 820 (RM 2,700) to encourage persons with disabilities to venture into small businesses. Dated to 2012, a total of 1,027 persons with disabilities have benefited from the grant (MoW 2013). In July 2000, the government expressed its commitment to protect the rights of disabled people by ratifying the Convention on the Rights of Persons with Disabilities (CRPD) and issued a policy to provide employment for them. As a result, in December 2012 there were 1,754 persons with disabilities employed in the public sector compared to 1,294 persons in 2009 (MoW 2013). Malaysian government has continuously issued undemocratic policies, e.g. the Sedition Act (OSA and ISA) ever since 1957. However, the government also created several progressive social policies for the education and health sectors, including a protection for people with disabilities.

In the midst of political turmoils, social policy in Thailand continued to increase steadily. In the midst of a political crisis in 2007, the government passed the Tenth NEDP (2007-2012), which placed more emphasizes on social harmony and sustainable co-existence among Thai society and natural resources and the environment (11th NEDP 2012). In 2007, The Person with Disabilities Quality of Life Act policy was issued to provide a comprehensive rights-based law for individuals with disabilities and contained an antidiscrimination component (ILO 2007). Disability NGOs previously did not get the support and facilities from the government. However, with this Act, these organisations acquired financial assistance from the government through the "Rehabilitation of Disabled Persons Fund." This fund is used to support the activities of NGOs to promote the rights of the disabled in accessing public services as well as to 
encourage them to involve in the policy making process (JICA 2012). In 2008, when the political situation in Thailand was very chaotic, the Ministry of Social Development and Human Security of Thailand, WHO and UNESCAP co-hosted the 1st Communitybased Rehabilitation (CBR) Asia-Pacific Congress from December 9th to 11th in Bangkok (JICA 2012). In the education sector, children from all socioeconomic groups had access to education at lower secondary level (TSM 2007).

\section{Inclusive Social Policies during Democratic Era}

In 1996, Indonesian movements of civil society organisations began to grow as the reaction on repressive political institutions during Suharto's reign. Facing a strengthened social criticism, the government began to introduce some social policies particularly for rural communities, education, and people with disabilities. Through the Ministry of Religion and Ministry of Education and Culture, government decided to provide financial aids to children with disabilities and school transportations for children living in remote areas to facilitate them to attend boarding schools (JICA 2002). In early 1998, the regime also developed a policy regarding technical requirements for public buildings to improve accessibility for persons with disabilities (JICA 2002). In short, it seems that social policies in the New Order regime only occurred when its economic and political conditions were ruined.

Another essential momentum of democratisation in Indonesia was about Abdurrahman Wahid who was elected as the fourth President of Indonesia. He was known as so-called "father of democracy" in Indonesia and one of Suharto's biggest enemies. When most of Indonesians fear the political stability jargon, President Wahid was committed to defending the rights of minorities in Indonesia. He deteriorated Islamic extremists after Christmas-eve bombings. He also held dialogues with ethnical separatists, avoiding a much-feared fragmentation of the nation (Tuck, 2001). However, Majelis Permusyawaratan Rakyat
(People's Consultative Council - MPR) impeached him due to these unpopular politics. His vice president, Megawati Sukarnoputri, then replaced him. Under his leadership, more institutional reforms were taken in the country. The Ministry of Transportation introduced mandatory regulations for transportation operators to improve accessibility for persons with disabilities and illness (JICA, 2002).

Later, the bargaining position of civil society began to grow. Regarding the social policy for people with disabilities, the government and the parliament officially ratified the Convention on the Rights of Persons with Disabilities (CRPD) in 2011. It was followed up with a couple of important high-level meetings related to the implementation of CRPD in Indonesia (UNESCO, 2014). Social policies currently taken by Indonesia are comprehensive and articulated in a numerous way by many ministries. For example, the Ministry of Social Welfare has been implementing 19 programs, e.g. Remote Indigenous Community Empowerment; Empowerment of the Poor; Rehabilitation and Social Protection for Children; Social Rehabilitation for Persons with Disabilities; Social Rehabilitation for the Socially Vulnerable; Social Protection for Migrant Workers and Victims of Violence and Abuse; Family Hope Program or the Conditional Cash Transfer (CCT), etc.

Thailand had been experiencing fragmented phases of democratic and undemocratic political system which affecting the inclusive social policies. In education sector, by 1976, the government established a policy compulsory primary education, with special provision for children with disabilities. With this policy, the dropout rate in Thailand was 60\% (in the 1960s) made it down to $2 \%$ in 1998 (TSM 2007). In 1980, Thai civilians began to indirectly influence policy-making in both national and local levels. The stronger position of civil society began during Prem Tinsulanonda becoming a government (Prime Minister from 1980 to 1988) who had a decent commitment to democratisation in Thailand (BTI 2014). One example of strengthening the civil 
society was the formation of many nongovernmental organisations (NGOs) of persons with disabilities, both at national and provincial levels. In 1983, these organisations actively influenced national and local government policies especially on developing careers and networking to protect the rights of persons with disabilities at the regional, provincial, district and community levels (JICA 2012). Cuan Leekpai government's commitment to social policy was also getting stronger. In this era, the prime minister has also signed the Declaration on Rights for People with Disabilities (December 3rd, 1998), which became the basis for providing basic services to people with disabilities in Thailand (JICA 2012). Social policy during the Thaksin administration directed more targets on rural poverty, as this can benefit Thaksin to strengthen his basis especially in the rural area. Other social policies include employment opportunities, providing 500 baht of monthly allowance to persons with disabilities (UNRC 2004).

In Philippines, the 1987 Constitution created by Aquino not only to reform the political institutions in Philippines to become more democratic, but also to incorporate aspects of social policies in which during the Marcos administration was largely ignored, especially in the sectors of education (UNESCO 2012). The 1987 Constitution also stipulated basic matters such as the recognition and enforcement of human rights, which will have consequences on the increasing liberty and freedom to all citizens. Another aspect that is very interesting of this constitution can be seen in section 13 article 13 which clearly indicates the importance of improving services for people with disabilities, as well as to specifically designate which agencies are responsible for carrying out these tasks (DRPI 2009). In general, the 1987 Constitution was a sign of a very strong commitment of the Corazon Aquino's administration towards democracy and social policies.

With an increasingly open democracy, the civil society organisations also increasingly have the opportunity to be involved in the policy-making process. The most prominent example was when NGOs the National Council for the Welfare of Disabled Persons (NCWDP) involved in the formulation of policies to reduce poverty in Philippines in 1997. A year later in 1998, the poverty reduction policies set the Republic Act 8425 which regulated several important things, such as the establishment of institutions for poverty reduction at central and local levels as well as the determination of fourteen sectors that became the focus of attention on programs of anti-poverty, including individuals with disabilities (DRPI 2009).

\section{Conclusion}

The impact of democracy on social policy may also be found in Christopher Hewitt's "simple democratic hypothesis" (in Roberts, 2005). His hypothesis argues that democracy enables a mechanism in which the demand of the poor and other marginalised groups (including persons with disabilities) are possible to enter policy development agenda. A pro-poor policy takes place as the result of electoral incentives from a free and fair election. Such mechanism occurs particularly in a country which use a plurality election system and wherein majority of the voters are poor. As Haggard and Kaufman (2008) emphasised such question by stating that among any other variables, democratic political institutions hence become a distinguished variable affecting the direction of social policy.

In sum, democracy enables civil society to become more strongly-organised and opens up rooms for negotiation. Under democratic institutions, civil societies are relatively free to organise themselves in order to enhance their bargaining position towards their state. Besides, civic organisations, such as labour unions, farmer organisations, teacher forums, people with disabilities, and pensioner associations, will relatively flourish in a democratic regime rather than in an authoritarian one. As the result, government in developing countries would like to allocate more budgets on welfare programs to satisfy the political pressure these groups demand. The size of 
public spending for social policy is also potentially in line with the improvement of welfare outcomes (Whitehead in Mkandawire, 2004; Stasavage, 2005; Bangura, 2007).

\section{References}

Roberts, Wade T. (2005), Global society embeddedness and democracy as pathways to the (social) developmental state: a crossnational study, National Science Foundation Dissertation Improvement Award (SES 0221278)

Haggard S and Kaufman R, (2008), Development, Democracy, and Welfare States: Latin America, East Asia, and Eastern Europe. Princeton University Press

Nelson, Joan M (2007), Elections, Democracy and Social Services, Comparative International Development, Winter 2007, Vol. 41, No. 4, pp. 79-97

Ido, Masanobu. (2012). Varieties of Capitalism, Types of Democracy and Globalization. Routledge

Mkandawire, Thandika (ed.) (2004). "Social Policy in Development Context". UNSRID and Palgrave MacMillan: New York.

Stasavage David (2005), Transparency, Democratic Accountability, and the Economic Consequences of Monetary Institutions, American Journal of Political Science, Vol. 47, No. 3, July 2003, Pp. 389402.

Bangura, Yusuf (ed.) (2007), Democracy and social policy, Palgrave MacMillan, New York.

Heckhausen, Jutta (1999): Developmental regulation in adulthood: Age-normative and socio-structuralconstraints as adaptive challenges. New York, NY: Cambridge University Press.

DiPrete, T. A. \&Eirich, Gregory M. (2006): Cumulative Advantage as a Mechanism for Inequality: A Review of Theoretical and Empirical Developments. Annual Review of Sociology 32: 271-297
McGregor, J. A. (2007) 'Researching wellbeing: From concepts to methodology', in Gough, I. and McGregor, J. A. (eds) Wellbeing in Developing Countries, Cambridge: Cambridge University Press

Glennerster, Howard. (2009). Social Policy: Now and Then - A Response. Social Policy and Administration. Volume 43, Issue 7, pages 750-753, December 2009

Baldock, John. (2011). Social Policy, social welfare, and the welfare state. Oxford University. UK

Levitas, R. (1996): The Concept of Social Exclusion and the New Durkeimian Hegemony. Critical Social Policy 16(46): 520

Rainbow, Paul (Ed.). (1997). Ethics: Subjectivity and Truth by Michel Foucault. The New Press: New York

Fendler, L. (2010). Michel Foucault. Continuum Library of Educational Thought, Vol. 22. Continuum Press: London.

Foucault, Michel. (2010). The Government of Self and Others: Lectures at the College de France 1982-1983). Palgrave Macmillan: New York.

\section{Data Sources:}

1. The Japan International Cooperation Agency (JICA) Planning and Evaluation Department released "Country Profile on Disability the Republic of Indonesia" in March 2002. The National Council for the Welfare of Disabled Persons (NCWDP) is responsible for the registration of persons with disabilities in collaboration with local governments, the Department of Social Welfare and Development (DSWD), and other organisations.

2. Permanent mission of the Republic of Indonesia to the United Nations, WTO and other international organisations released in 2010 regarding Human rights of persons with disabilities. 
3. The Government of Indonesia ratified the United Nations Convention on the Rights of Persons with Disabilities (UNCRPD) in October 2011 creating a momentum in the advancement of the rights of persons with disability. UNESCO Office Jakarta's project "Social Inclusion of People Living with Disabilities in Indonesia" is part of a collaborative UN effort supported by the United Nations Partnership for the Rights of Persons with Disabilities that aims to promote dissemination and implementation of the U.N. Convention on the Rights of Persons with Disabilities (UNCRPD).

4. Monitoring the Human Rights of Persons with Disabilities: Laws, Policies and Programs in Philippines. Disability Rights Promotion International (DRPI) and Katipunan $\mathrm{Ng}$ Maykapansanan sa Pilipinas, Inc. The goal of the program is to improve the quality of life of PWDs by adding social and economic provisions like the $20 \%$ discount on purchase of medicine and daily essentials including transportations and recreational services.

5. Statement by her Excellency Rohani Abdul Karim, Minister of Women, Family and Community Development of Malaysia presented in high-level meeting of the general assembly on the realisation of the millennium development goals and other internationally agreed development goals for persons with disabilities round table no. 2: "post-2015 development agenda and inclusive development for persons with disabilities".

6. Department for the Development of PWDs Department of Social Welfare published a National Social Policy of Malaysia: Perspective On Inclusive Development: "Embracing Diversity And Creating Disability sensitive Communities" in July 2010.

7. "Country Profile on Thailand" published by JICA in 2012. This document is a report on Thematic Evaluation on JICA's Support for Persons with Disabilities in Thailand. 